\title{
Air Caloric Test による簡易前庭機能検査の検討
}

\author{
豊田 健司・涌井 慎哉・津田 豪太 \\ 坂下 勤武・岩城 詠子・斎藤 等
}

Evaluation of Vestibular Function by the Air Caloric Test

\author{
Kenji Toyoda, Shinya Wakui, Gota Tsuda, \\ Tsutomu Sakashita, Eiko Iwaki and Hitoshi Saito \\ (Fukui Medical School)
}

\begin{abstract}
We performed the air caloric test in 22 normal ears, and confirmed that changes in the maximum slow phase velocity are nearly linear with changes in the air temperature between 10 and $50^{\circ} \mathrm{C}$.

From the velocity-temperature curve obtained by the above evaluation, the conditions of $15^{\circ} \mathrm{C}$ air, $61 / \mathrm{min}$, and 60 seconds were considered to be optimal for producing responses similar to those obtained when using $5 \mathrm{ml}$ water at $20^{\circ} \mathrm{C}$ infused over 20 seconds. The results of the air caloric test and the water caloric test performed under these conditions in patients with vertigo were comparable. Judging from these findings, the air caloric test is considered to be a useful examinations of vestibular function.
\end{abstract}

Key words: air caloric test, screening test, vestibular function

\section{はじめに}

Air caloric test は現在，瀶床的に実用化され ている方法であるが，鼓膜穿孔や耳垢などで耳 内が湿潤している場合には，前庭系の異常がな いにもかかわらず，温刺激に対していわゆる

\section{表। Air Caloric Test の利点と欠点}

[利点]

・温度設定が簡易で，準備に時間がかからない.

・反応に，ばらつきが少なく確奏である.（乾燥耳）

・被験者に対する耳内不快感が少ない。

・慢性中耳炎などの症例でも病変の増悪を眯念するこ となく施行できる.

[欠点]

・鼓膜穿孔耳など，耳内が湿潤している場合には錯倒 反応をおこすことがある。
鍇倒反応がおこることが多数, 報告されてい る1) .5). しかし, air caloric test には表 1 のご とく，水を利用した caloric test に比べいくつ かの利点がある。これらの利点を利用して平衡 神経外来を受診する多くのめまい患者の前庭系 の買常の有無を調べるスクリーニングとして air caloric testをより有効に利用することはで きないかと考光，そのための送風条件をいろい ろと検討したので報告する。

\section{対象および方法}

1) 視診上, 鼓膜に第孔がなく, 耳内が乾燥し ている正常耳 22 耳に対して, $10^{\circ} \mathrm{C}, 20^{\circ} \mathrm{C}, 30^{\circ} \mathrm{C}$, $40^{\circ} \mathrm{C}, 50^{\circ} \mathrm{C}$ と, 6 種の温度で air caloric test を施行し, 各温度で最大緩徐相速度がどのよう に変化するかを調べてみた。な拈送風は山崎

福井医科大学耳鼻咽喉科学教室 


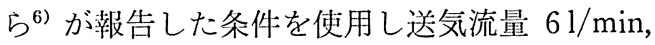
刺激時間60秒で行った。

検査の実施にあたり，被験者は仰臥位で頭位 を水平面より30度前屈位とし，隌所フレンツェ ル眼鏡下で検查を施行した。眼振は電気眼振計 （ENG）で記録し，被験者の意識レベルを保つ ために送風開始直後より逆隌算を命じた.

2 ）水による coloric test の刺激条件としては $30^{\circ} \mathrm{C}$ および $44^{\circ} \mathrm{C}$ の冷温交互刺激が標準的で あるが，この方法は時間がかかるため，スクリ ーニングのための簡便法として, $20^{\circ} \mathrm{C}, 5 \mathrm{ml} 20$ 秒間の少量注水法が提坚されて执り, その条件 下での最大緩徐相速度が 10 度/sec 以下のもの に対して CP と診断してよいとされている7) 9). この注水法を air caloric test で代用する際に水 注入と同程度の反応を得るための送風条件を求 めた.さらに，ここで得られた条件を夹際のめ まい患者に適応し，その妥当性を検討した。

\section{結果}

図 1 に注入空気温度と最大緩徐相速度との関

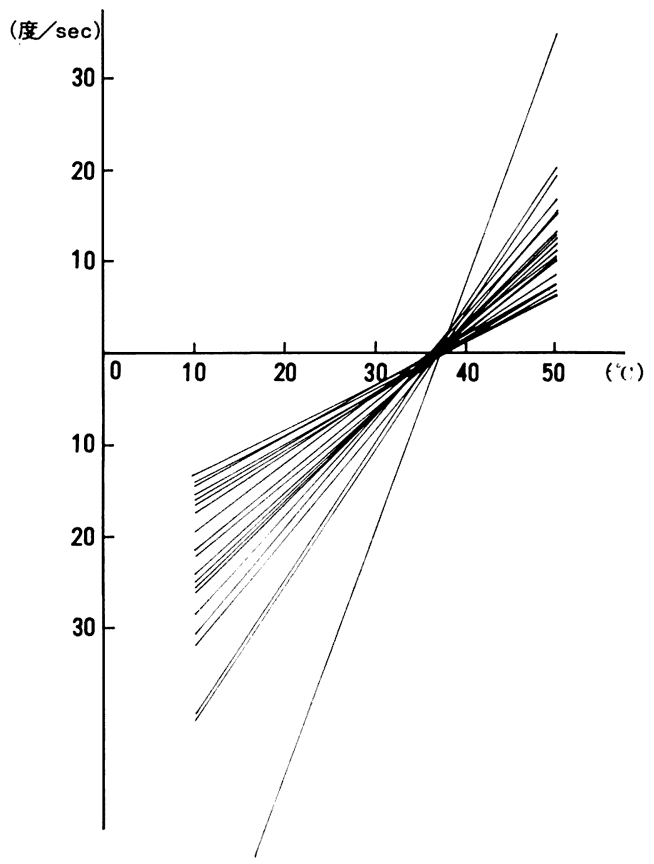

図 I Air Caloric Test による各温度での 最大緩徐相速度の変化 (正常乾燥耳)
係を示した，横軸に温度，縦軸に最大緩徐相速 度を示しているが，図のごとく $10^{\circ} \mathrm{C}$ から $50^{\circ}$ Cにおいては，最大緩徐相速度は温度にほぼ比 例した変化を示すことがわかる. $10^{\circ} \mathrm{C}$ 以下， また $50^{\circ} \mathrm{C}$ 以上では被験者の不快感がかなり強 く,さらに $10^{\circ} \mathrm{C}$ 以下になると通風口に水滴が 生ずることがあり正確な温度設定が不可能で， $10^{\circ} \mathrm{C}$ 以下 $50^{\circ} \mathrm{C}$ 以上でどのような変化をする かは不明である。

次に簡易前庭検査法としての $20^{\circ} \mathrm{C}$ 少量注水 法（20秒間刺激, 上村他 ${ }^{8)}$ ) と同程度の反応を得 る送風条件を求めることにより短時間で CP の 診断を可能にしたいと考え検討した，図 2 はこ の送風条件を求めた方法であるが，この被験耳 では少量注水法での最大緩徐相速度が 14度/ sec であったのでこれに対応する air caloric test での温度は $15^{\circ} \mathrm{C}$ と求められた。 この仮定 条件をもとに，22耳に対して少量注水法に対応 する air caloric test の垁際の温度を決定した。

図 3 はその結果である. 平均 $15.4^{\circ} \mathrm{C}$ ，標準 偏差 $1.4^{\circ} \mathrm{C}$ であった. この結果から, 少量注水 法 $\left(20^{\circ} \mathrm{C}, 5 \mathrm{ml}, 20\right.$ 秒間) に対する air caloric

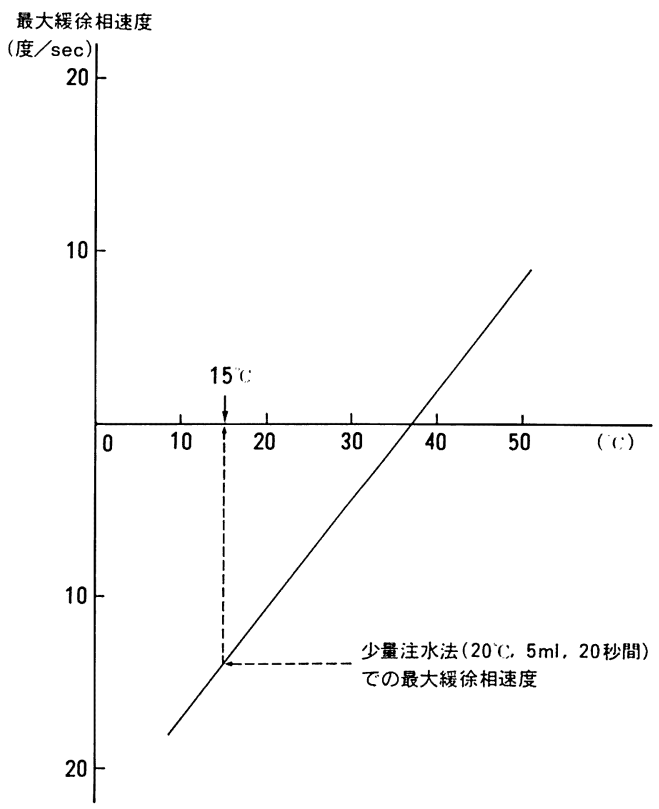

図 2 少量注水法と同反応を得る送風温度の求め方 
test の刺激条件は $15^{\circ} \mathrm{C}$ air, $61 / \mathrm{min}, 60$ 秒間で よいことが判明した。

次にこの設定条件での持続時間を少量注水法 と比較したのが表 2 である. 30 秒〜 50 秒ほど air caloric test の方が持続時間が長いことが認 められた。

ついで当院めまい外来を受診しためまい患者 のらち，視診上鼓膜に第孔がなく耳内が湿潤し ていない30耳に対して, $15^{\circ} \mathrm{C}$ air caloric test (61/min, 60 秒間) と $20^{\circ} \mathrm{C}$ 少量注水法を各々施

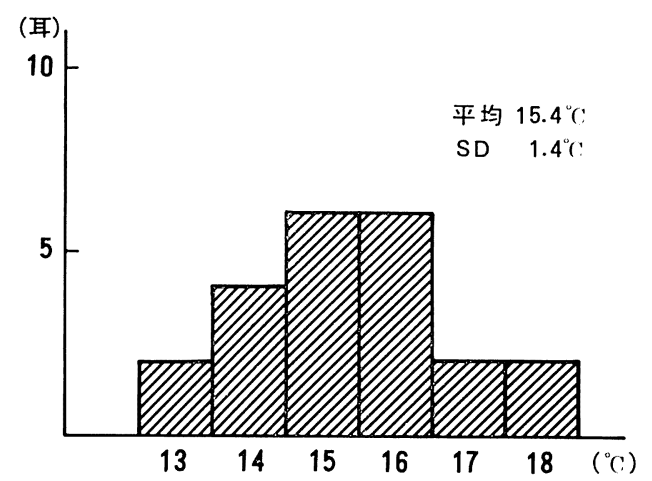

図 3 少量注水法 $\left(20^{\circ} \mathrm{C}, 5 \mathrm{ml}, 20\right.$ 秒) に 対応与る Air Caloric の温度
行し, 最大緩徐相速度を比較してみた. 図 4 が その結果であるが，明らかに雨者の間には相関 があり，ほぼ同程度の結果が得られることが判 明した。

\section{考察}

Air caloric test という便利な刺激装置が開発 されて以来これらを利用して, 従来から用いら れてきた注水による刺激条件に準ずる送気刺激 の条件設定が行なわれてきた. Capps ら ${ }^{10)}$ は air caloric test と注水による温度眼振反応を比

表 2 少量注水法との持続時間の比較

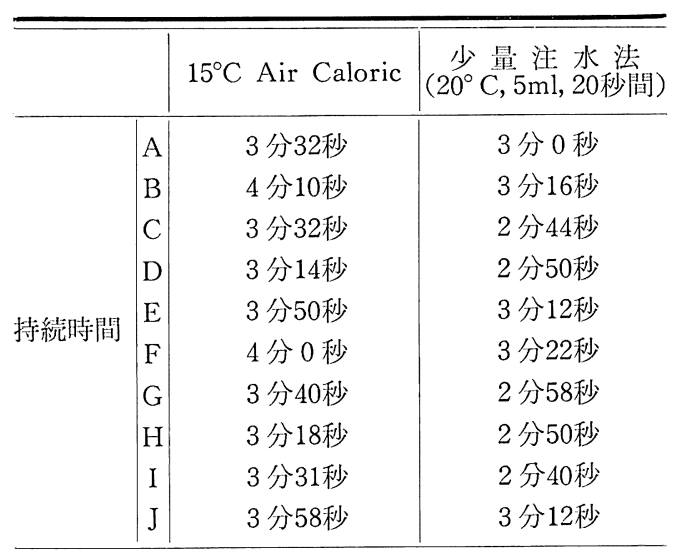

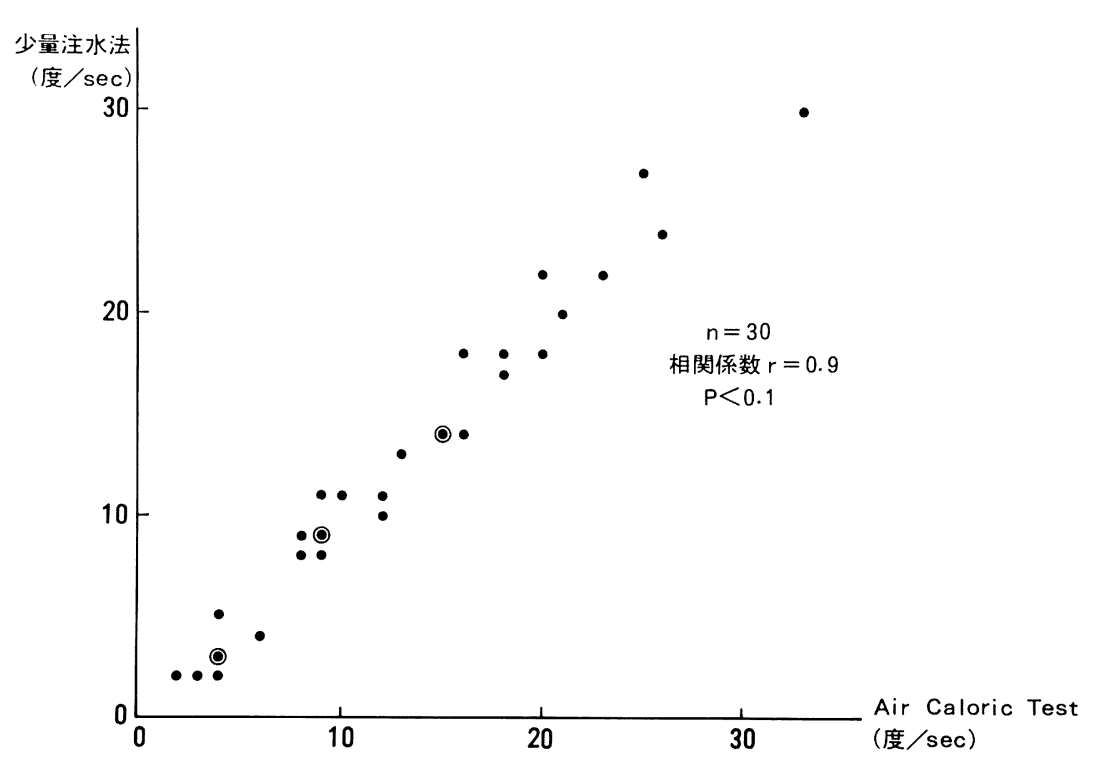

図 4 少量注水法との最大緩徐相速度の比較 
較し, $30^{\circ} \mathrm{C}$ 抢よび $44^{\circ} \mathrm{C}$ の注水 30 秒間には $24^{\circ}$ $\mathrm{C}$ 扣よび $50^{\circ} \mathrm{C}$ air, $81 / \mathrm{min}, 60$ 秒間刺激が相当

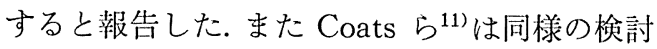
を行い $25^{\circ} \mathrm{C}$ 抢よび $47^{\circ} \mathrm{C}$ air, $10 \mathrm{l} / \mathrm{min}, 60$ 秒 間刺激が $30^{\circ} \mathrm{C}$ および $44^{\circ} \mathrm{C}$ の注水 30 秒間の眼 振反応に相当するとしている。本邦では竹田 ら ${ }^{1)}$ が，従来より行われてきた冷温交互試験 $\left(30^{\circ} \mathrm{C}, 44^{\circ} \mathrm{C} 50 \mathrm{ml}, 20\right.$ 秒間注水，大谷 $\left.{ }^{12)}\right)$ とほ ぼ等価となる刺激条件，すなわち $24^{\circ} \mathrm{C}$ 抢よび $50^{\circ} \mathrm{C}$ の air, $6 \mathrm{l} / \mathrm{min}, 50$ 秒間刺激を報告してい る. 山崎ら ${ }^{6)}$ は $24^{\circ} \mathrm{C}$ および $50^{\circ} \mathrm{C}$ air, 6l/ $\min , 60$ 秒間刺激が, 従来の冷温交互試験 ${ }^{12)}$ 之有 意の差がないと報告しており，これが現在 air caloric test の一般的送風条件として使用され ている．今回我々は，前述した表1にあるさま ざまな air caloric test の利点を生かし，スクリ ーニングとして air caloric testを利用するため に，簡易前庭検査法として提坚されている $20^{\circ}$ C 少量注水法 ${ }^{8}$ に相当する送風条件を求め, $15^{\circ}$ C air, 6 l/min，60秒間と決定した.

この刺激条件での air caloric test と $20^{\circ} \mathrm{C}$ 少量注水法とを比較した結果, 持続時間に扔い て30秒から50秒間ほど air caloric test の方が長 いことが判明したが，これは少量注水法での刺 激が検查開始ほぼ数秒で与えられるのに対し て, air caloric test では外耳道温度が平衡状態 に達するのに約 40 秒くらいかかるといら山崎 ら での時間の差が原因と推測され，そのことを考 慮に入れるとほぼ同程度の持続時間であると考 えられ，最大緩徐相速度における比較では雨者 に有意に相関があることもあわせて, $15^{\circ} \mathrm{C}$ air， $6 \mathrm{l} / \mathrm{min}, 60$ 秒間刺激は $20^{\circ} \mathrm{C}$ 少量注水法に相当 する反応が得られるものと考劣る。

従来の注水による温度眼振検查に比べて, air caloric test は刺激温度の設定が容易で誤差 が少ないこと，検查手技が容易で被験者の不快 感も注水に比較して格段に少なく，簡便にベッ ドサイドで行いらる脳幹機能検查法として用い

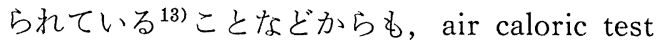

は注水法に比較して充分優れた検査法であると 思われ，さらに今回の我々の設定条件で行えば 短時間で CP の診断を可能にできると考える.

慢性中耳炎など中耳感染例にでも air caloric test は利用できる利点がある反面，鼓膜穿孔耳 を含め耳内が湿潤している場合に錯倒反応が拉 こることが air caloric test を行う上で大きな問 題点となっているが，現在この発現機序は未だ 不明である．水刺激による温度眼振検査では錯 倒反応を認めないことなどから, air caloric test のもつ特徵, すなわち風圧, 比熱および迷路に 対する熱伝導機構などに問題があると考えられ て㧍り ${ }^{3)}$ ，その中でも特に中耳粘膜表面の水分 気化による冷却効果が原因とされ，これを実証 するために動物実験，耳モデルでの実験，臨床 的実験, 症例検討, 熱伝導計算などが行われて (るる2)5)14)15).

この錯倒反応を防止するために飽和加湿空気 を送るなどの方法が報告されている5 が，今後 錯倒反応の原因を究明し，これをいかに防ぐか が, air caloric test の有用性をさらに高める上 で重要な課題であると考える.

\section{まとめ}

1 ） air caloric testによる最大緩徐相速度は

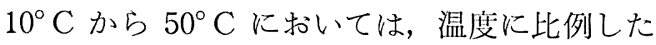
変化を示した。

2) 少量注水法 $\left(20^{\circ} \mathrm{C}, 5 \mathrm{ml}, 20\right.$ 秒間) に対応 する air caloric test の刺激条件は, $15^{\circ} \mathrm{C}$ air, $6 \mathrm{l} / \mathrm{min}, 60$ 秒間刺激であると決定した。

3 ) air caloric test は刺激温度の設定が容易 で愦差が少なく, 被験者の耳内不快感も注水に 比較して格段に少なく，前庭機能検查のスクリ ーニングとして有用であると結論した。

本論文の要旨は, 1987年第46回日本平衡神経科学会 総会に捄いてロ演した.

\section{参考文献}

1) 竹田泰三, 北原正章 : Air caloric test. 耳鼻臨休 $70: 115 \sim 118,1977$.

2 ) Barber HO, et al : Air caloric stimulation with tympanic membrane perforation. Laryngoscope 
$88: 1117 \sim 1126,1978$.

3) 北真行, 森弘, 堀内政子, 他 :Thermoelectric Air Stimulator による Air Calorc Test に ついて. 耳鼻臨床 $71: 27 \sim 34,1978$.

4) 山崎晴子：Air Caloric Stimulator による温度性 眼振反応の定量的分析に拈ける問題点. 日耳鼻 $83: 619 \sim 631,1980$.

5 ) 吉川由繪, 飯田 順, 渡来潤次 : 鼓膜穿孔耳にお ける Air caloric test 温刺激に対する錯倒反応の 発現機序とその防止対策. Equilibrium Res 44 : 53, 1985.

6 ）山崎崝子, 水越鉄理, 石川和光, 他 : Air Caloric Test (判定基準を中心に). 日耳鼻 80 ：814 818, 1977.

7 ）上村卓也：温度眼振検查. 平衡機能検查の実際 (日本平衡神経科学会編).192 203頁, 南山堂, 東京, 1986 .

8 ) 上村卓也, 他: 温度刺激 検查. 神経耳科学 検査 法. 85 98頁, 医学書院, 東京, 1968.

9 ）上村卓也, 他 : 少量注水法に上る温度眼振検査の 診断的意義. 耳鼻臨床 補 $2 ： 148 \sim 155,1986$.
10) Capps MJ, et al : Evaluation of the air caloric test as a routine examination procedure. Laryngoscope 83: 1013 1021, 1973.

11) Coats AC, et al : The air caloric test, a parametric study. Arch Otolarynagol 102:343 354, 1976.

12）大谷 務: 前庭反応の判定基準. 日耳鼻 $65: 524$ $\sim 543,1962$.

13）中里明彦：重症心身障害児にお打る air caloric test の検討. 日本小児学会誌 $88: 1550 \sim 1558$, 1984.

14）吉川由繪, 飯田 順, 古野隆之, 他: 鼓膜穿孔耳 における Air caloric test 温刺激に対する錯倒反 応の発現機序. 日耳鼻 $88: 53 \sim 54,1985$.

15）吉川由繪, 大竹英夫, 戸田行雄, 他 : Air caloric

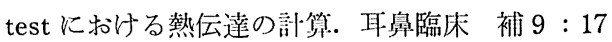
$\sim 23,1987$.

/別刷請求先：豊田健司

$\left(\begin{array}{l}\text { T602 京都市上京区河原町通広小路上儿梶井町 } 465 \\ \text { 京都府立医科大学耳鼻咽喉科学教室 }\end{array}\right)$ 